\title{
Perceptions of Amanah Ikhtiar Malaysia Borrowers about the Need for Other Aid from AIM besides Financial Aid Credit
}

Nor Aishah Mohamed \& Muhammad Hussin

To Link this Article: http://dx.doi.org/10.6007/IJARBSS/v12-i1/12353

DOI:10.6007/IJARBSS/v12-i1/12353

Received: 13 November 2021, Revised: 11 December 2021, Accepted: 01 January 2022

Published Online: 17 January 2022

In-Text Citation: (Mohamed \& Hussin, 2022)

To Cite this Article: Mohamed, N. A., \& Hussin, M. (2022). Perceptions of Amanah Ikhtiar Malaysia Borrowers about the Need for Other Aid from AIM besides Financial Aid Credit. International Journal of Academic Research in Business and Social Sciences, 12(1), 2742-2748.

Copyright: (c) 2022 The Author(s)

Published by Human Resource Management Academic Research Society (www.hrmars.com)

This article is published under the Creative Commons Attribution (CC BY 4.0) license. Anyone may reproduce, distribute, translate and create derivative works of this article (for both commercial and non0-commercial purposes), subject to full attribution to the original publication and authors. The full terms of this license may be seen at: http://creativecommons.org/licences/by/4.0/legalcode

Vol. 12, No. 1, 2022, Pg. $2742-2748$

Full Terms \& Conditions of access and use can be found at http://hrmars.com/index.php/pages/detail/publication-ethics 


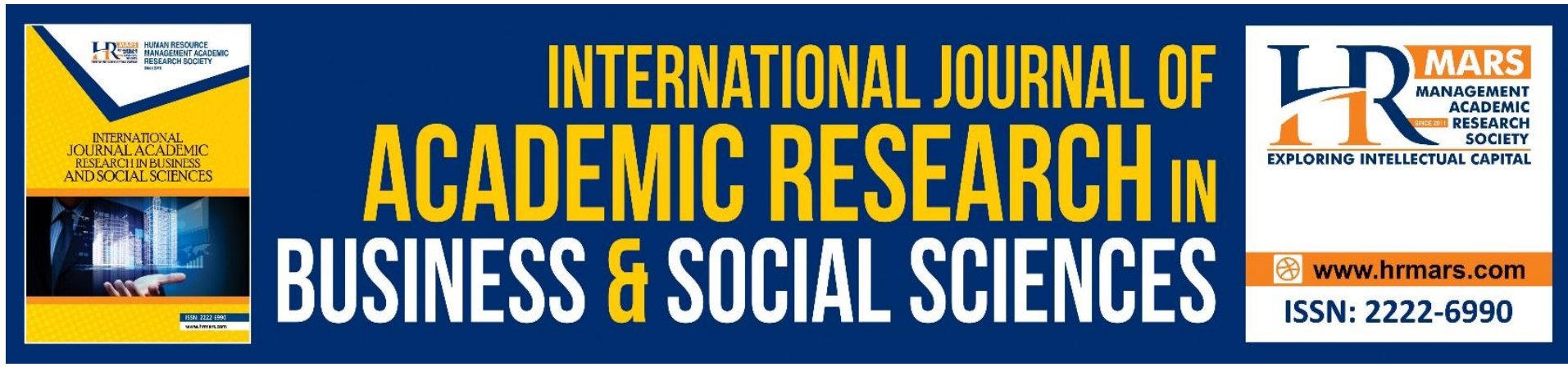

\title{
Perceptions of Amanah Ikhtiar Malaysia Borrowers about the Need for Other Aid from AIM besides Financial Aid Credit
}

\author{
Nor Aishah Mohamed \& Muhammad Hussin \\ Faculty of Education Universiti Kebangsaan Malaysia 43600, Bangi Selangor, Malaysia
}

\begin{abstract}
This study is a qualitative study based on case study design involving an interview with a total of six participants. This study used Proportional Stratified Random Sampling. All participants consisted of AIM borrowers in Terengganu. The qualitative analysis of data used interview transcript analysis. Findings of the study showed that the level of entrepreneurial thinking is high (mean $=4.21$; s.p $=0.47$ ), while the level of entrepreneurial behavior is low (mean $=2.33$; s. $p=0.51$ ) and the level of entrepreneurial competency is moderate (mean $=3.39$; s.p: 0.57 ). The findings from the interview showed that overall there is a need for AIM microcredit financing in terms of business resilience based on the aspects of strengthening financial management, building the mental resilience of entrepreneurs and operational efficiency. The implications from the findings of this study suggest that AIM programs should be continued but some weaknesses need to be improved especially from the aspect of education and training to AIM borrowers.
\end{abstract}

Keywords: Amanah Ikhtiar Malaysia, Microcredit Scheme, Economic Well-being, Well-being, Entrepreneurship

\section{Introduction}

AIM has recorded a total of 377,380 total borrowers from the beginning of the establishment until April 2019 in which more than 98 percent of repayments have been made (Berita Harian, 2019). Currently, there are 136 AIM branches throughout Malaysia with a total number of borrowers (Sahabat AIM) of 132, 283 people in which 106,503 people are in Peninsular Malaysia and the remaining 25,780 people are in Sabah and Sarawak (Official Bulletin of Koperasi Sahabat AIM Berhad, 2019). Of the total number of AIM borrowers in Peninsular Malaysia, the highest number of AIM borrowers is in the states of Kedah and Perlis, followed by Terengganu, Perak and Penang and Kelantan (Table 1.1). 
Table 1.1 Total Number of AIM Borrowes in Penisular Malaysia, 2019.

\begin{tabular}{lll}
\hline State & Number of AIM Borrowes & Percentage (\%) \\
\hline Kedah dan Perlis & 25,787 & $24.21 \%$ \\
Terengganu & 15,051 & $14.13 \%$ \\
Perak dan P.Pinang & 14,592 & $13.70 \%$ \\
Kelantan & 14,150 & $13.29 \%$ \\
Pahang & 10,148 & $9.53 \%$ \\
Selangor & 9,697 & $9.10 \%$ \\
N.Sembilan dan Melaka & 7,381 & $6.93 \%$ \\
Johor & 9,697 & $9.10 \%$ \\
\hline Total & $\mathbf{1 0 6 , 5 0 3}$ & $\mathbf{1 0 0 . 0 0 \%}$ \\
\hline
\end{tabular}

Source: Buletin Rasmi Koperasi Sahabat AIM Berhad (2019).

The selection of the study area is based on the rate of poverty reduction in the state of Terengganu (1.1\%) compared to the states with the highest number of AIM borrowers in Peninsular Malaysia, namely Kelantan (1.8\%), Perlis (1.7\%), and Kedah (1.4\%), although Terengganu is the second highest state in terms of the number of AIM borrowers (Department of Statistics Malaysia and Economic Planning Unit, 2019). In fact, according to Ibrahim et al (2016), efforts to increase income among poor and hardcore poor families in Terengganu should be given serious attention based on the findings of the study that found the respondents' level of satisfaction with the family economy such as total income, property ownership and the level of job opportunities are low.

Table 1.2 Rate of Poverty Reduction of Selected States in Penisular Malaysia.

\begin{tabular}{llll}
\hline State & $\mathbf{2 0 1 7}(\boldsymbol{\%})$ & $\mathbf{2 0 1 8} \mathbf{( \% )}$ & Rate of Poverty Reduction (\%) \\
\hline Kelantan & 2.7 & 0.9 & 1.8 \\
Perlis & 1.9 & 0.2 & 1.7 \\
Kedah & 1.7 & 0.3 & 1.4 \\
Terengganu & 1.7 & 0.6 & 1.1 \\
\hline
\end{tabular}

Source: Department of Statistics Malaysia and Economic Planning Unit, 2019.

This study was conducted using qualitative analysis approach to identify the factors of entrepreneurial thinking, entrepreneurial behavior and entrepreneurial competency of AIM borrowers and their relationship with the success of AIM entrepreneurs. The main focus is on exploring the perceptions of AIM borrowers on the need for other aids from AIM in addition to financial aid credit. It is hoped that this study will contribute to the understanding of the factors that drive the success of AIM entrepreneurs in terms of the economic well-being of AIM borrowers' households based on the aspect of asset ownership, as well as total income and income distribution. In addition, this study is expected to be used as an important guide and input to all parties, especially AIM in formulating strategies, initiatives and programs that are more effective to increase business resilience and further improve the household wellbeing of AIM borrowers.

\section{Literature Review}

Plsek's Mechanics of Mind theory (1997) describes the thought process that takes place in the mind of an individual. Plsek's Mechanics of Mind theory (1997) consists of four components namely perception, memory, evaluation of ideas and high level thinking. Plsek 
(1997) explained that environmental conditions will be observed through the mind system that is perception. Next, input from the environment will be understood through perception and memory. Thus, the subsequent evaluation of ideas will influence individual actions. All the processes that take place are controlled by high-level sub-systems of thought.

The Creative Thinking Model is part of the concept of creative teaching (Reily, 2011). Creative teaching is an effective teaching process when there is a combination of existing knowledge with the burst of new knowledge and ideas to produce more meaningful results (Torrance, 1979; Plsek, 1997). Creative thinking among entrepreneurs is very important because high creativity helps to increase the ability of individuals in generating new ideas and inventions, mastering various cognitive skills, able to face competition and solve complex problems in the world of business and entrepreneurship.

Plsek (1996) later concluded that at the preparatory stage, creative observation starts from environmental observation. Next, the observation process leads to the generation of new ideas. All ideas will be evaluated and considered carefully before action is taken to make the idea a reality. Next, Plsek (1996) stated three (3) principles in creative thinking namely i) attention, ii) past, and iii) movement. According to Plsek (1996), the attention of the mind will provide discovery to creativity if one focuses on something that was previously ignored. The second principle is to let go of the thought to generate creative ideas. The third principle is movement which is to force a person to explore and make connections of their thoughts. Figure 2.7 shows the model of (Plsek's Directed Creativity Cycle, 1996).

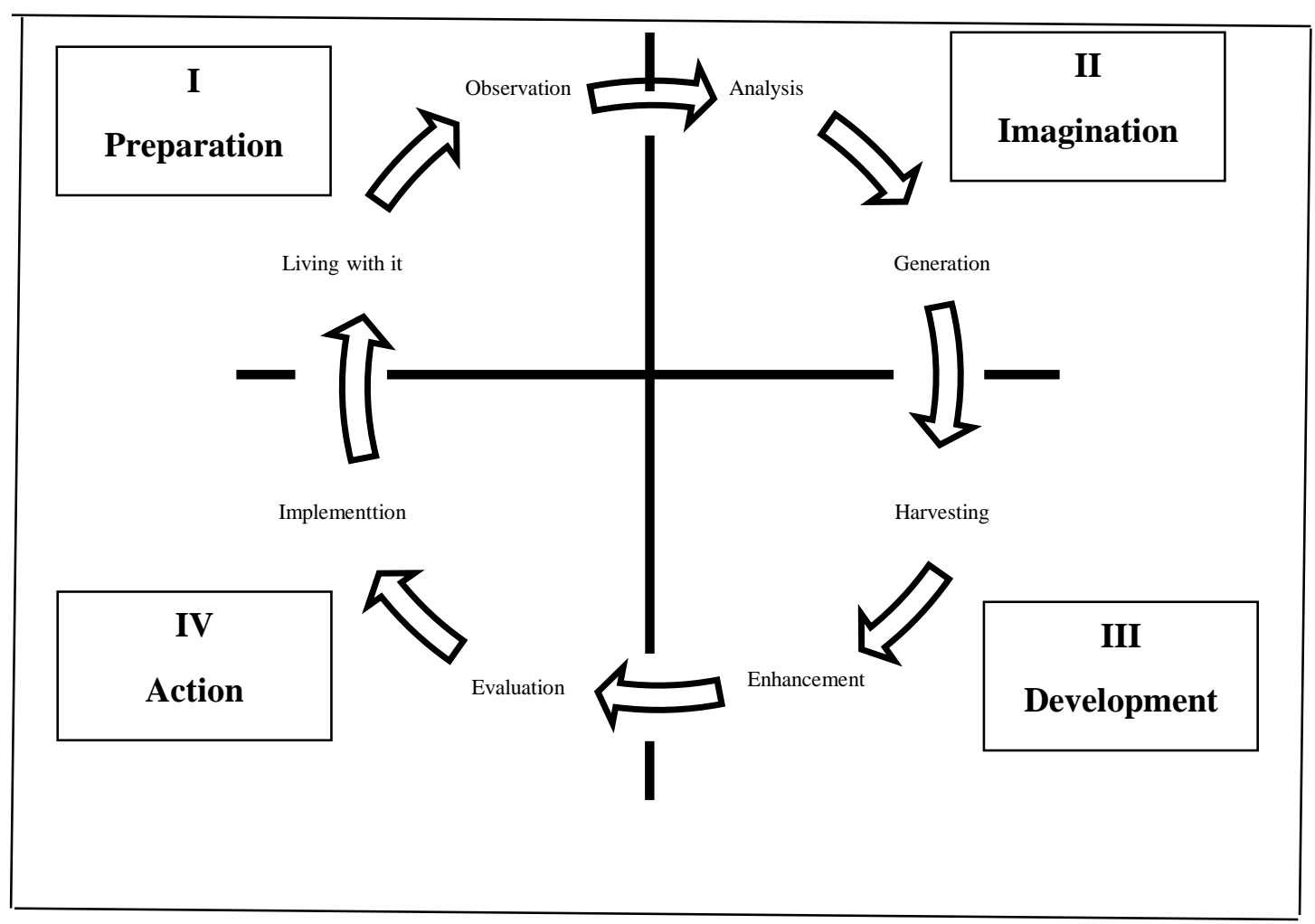

Figure 2.7: Plsek's Directed Creativity Cycle Model

Source: Plsek (1996)

\section{Methodology}

In preparing the qualitative analysis, the researcher focused on the interviewed participants' perspectives about the needs of microcredit loans from AIM in terms of business 
resilience capabilities based on the taxanomy of Malay women entrepreneurs by Sidal (2014). The researcher conducted a face-to-face semi-structured interview on AIM borrowers to obtain more in-depth information in order to provide an explanation to questions that may have doubts. The process of data collection was done simultaneously with the process of analysing the data to help researchers form an effective, in-depth and more comprehensive meaning (Merriam, 2009). Before the data was placed in the form of categories, researchers had openly coded it (Strauss \& Corbin, 1998).

Meanwhile, to determine the participants for the interview, in line with the fifth objective of the study which is to explore the perceptions of AIM borrowers about the need for AIM microcredit loans in terms of business resilience, purposive sampling technique was used. The researcher assumed that the researcher wants to explore and understand the perception of AIM borrowers on the needs of AIM microcredit loans in terms of resilience, so the need to select study participants is placed on potential participants in the field of entrepreneurship and have an understanding of the purpose of microcredit loans. Therefore, based on Merriam (2009) suggestion, the researcher first identified the main criteria of the study's participants and location. Thus, the main features of the selection of interviewed participants are as follows:

1. Loan participation period is more than five years.

2. Have made a loan of at least RM5000 and above

In qualitative studies, the total number of study participants is unlimited in number (Merriam, 2009). Accordingly, a total of six participants were involved as the participants for the interview. According to Yin (2003), the sample size should not be too small to make it difficult for the researcher to achieve data saturation and if there are too many, the researcher would find it difficult to explore the study conducted in more depth. Therefore, the researcher needs to ensure that the number of participants involved in the interview is able to answer all the research questions provided (Marshall \& Rossman, 1999).

\section{Data Analysis and Results}

The findings from the analysis of the interviewing the participants showed the need for a microcredit loan from AIM in terms of business resilience, according to the borrowers' view, is for i) motivation and commitment, ii) business management abilities, and iii) market dominance. These three themes were formed based on seven categories namely a) internal motivation, b) external motivation, c) attitude, d) cognitive abilities, e) financial management, f) promotion, and g) branding.

The most important finding obtained from the interview analysis was that AIM borrowers have demonstrated their understanding of the concept of AIM microcredit loans. In turn, this leads to an understanding of the microcredit financing requirements from AIM on the resilience of their business. The participants stated that there is a need in AIM microcredit loans to increase the resilience of their business in terms of better financial management.

According to the participants, the loan from AIM has helped them to repay the debt to the supplier as well as using it as capital to do business either initial business capital or revolving capital. This is in line with the goals and efforts made by AIM which aims to help the poor women start economic activities in the field of entrepreneurship to help create small businesses, increase the opportunity for women to play a role as employers and as the best 
alternative to overcoming debt problems with moneylenders (Aini, 1999). This effort has also succeeded in proving that AIM financing aid can increase household activities as employers in which a total of 134,800 female employer entrepreneurs were successfully born compared to 7,500 male employer entrepreneurs (Department of Statistics Malaysia, 2016).

This is in line with the role of microcredit financing highlighted by Dr. Mohammad Yunus to help poor households generate income through micro activities in improving their well-being (Francis, 2013). In fact, this financial aid also enables the poor to improve their standard of living in education and health as well as meet various other cash needs (Coleman, 2002; Littlefield et al., 2003). In Malaysia, previous studies have found that the importance of microcredit aid not only affects the business success of small entrepreneurs. In fact, the overflow impact on the well-being of the borrowers' family as a whole especially in terms of total income and income distribution can be observed.

In addition, the need for AIM microcredit financing can also be seen in terms of building mental strength in business based on attitude and self-confidence. According to Safura et.al (2016), entrepreneurial attitude is able to shape good behaviour thus influencing entrepreneurial success. A positive attitude will help entrepreneurs to strive and expand their business. This is because the attitude of an individual gives clear direction and stimulates the success of entrepreneurs because the dissatisfied attitude with success allows the entrepreneur to make long-term predictions about the practices, opportunities and threats that exist in their business. This view is in line with McClelland and McBer (1985) who stated that the attitude of entrepreneurs who have data to see and seize opportunities can increase the level of competency through existing business opportunities. Through the ability of seeing and seizing opportunity, an entrepreneur is able to expand the market in running business.

In the Organisational Behaviour Theory, individual attitudes can predict the level of desire to shape behaviour. Several previous studies have shown that attitude is an important element that can stimulate behaviour (Ravi, 2015; Salleh et al., 2005; Aziz \& Zakaria, 2004).

For example, if an individual has a positive attitude towards something, acceptable social norms and a high level of perception of behaviour control, these will lead to an individual's behaviour forming intentions (Ajzen \& Fishben, 1991). Yusof and Sapiah (2014) also emphasised that attitude is one of the important aspects in being a successful entrepreneur. Honesty and trust are very important in shaping the personality of a successful and noble entrepreneur. In fact, honesty and responsibility will always be esteemed by society in line with the view of Hailes (1993) who stated that the most important asset in the entrepreneur is the attitude of the entrepreneur who will determine the success of the business.

Furthermore, the findings from the interview analysis also found that there is a need for AIM loans in terms of business resilience through more efficient operations management. According to the participants, their business became more organized in terms of time and finances. Through AIM financing aid, entrepreneurs became more disciplined towards the weekly repayment time of their loans. Participants also admitted that they started segregating personal and business expenses after receiving advice and guidance from AIM on financial management. This corresponds with the view of Aini (1999) who stated that the effort done by AIM is aimed to help poor women start economic activities in the field of entrepreneurship in creating small businesses, increase women's opportunities as employers and as the best alternative for overcoming the problem of borrowing with moneylenders.

Therefore, through the above discussion, the researcher can conclude that microcredit financing from AIM is very important for small entrepreneurs because the loan 
they receive not only overcome the financial problems of entrepreneurs but also help entrepreneurs to be more viable in business. Most of the participants that have been interviewed expressed that the microcredit aid from AIM has helped them in learning how to manage their finances better. Apart from that, the unsecured loan aid from AIM is like a savior to their efforts in earning a living. Aid and guidance from AIM has given them the mental strength to continue to engage in entrepreneurship.

\section{Conclusion}

Findings from the interview analysis found that overall, AIM borrowers have a very positive view on the efforts made by AIM in helping small entrepreneurs to be resilient in business and growing their existing businesses. Among the main points highlighted by the participants on the need for microcredit financing from AIM in terms of business resilience are motivation and commitment, business management capabilities and market dominance.

Overall, this study shows that the findings were relevant to the current situation in Malaysia where small entrepreneurs who take microcredit loans from AIM respond positively to their success in entrepreneurship in terms of family economic well-being. AIM borrowers are aware of the importance of improving the well-being of their lives through the business they run even on a small scale. The aspiration in improving the level of well-being of their lives is expected to further increase the level of entrepreneurs' success consisting of these AIM microcredit borrowers at the optimum level if education and training programs are implemented more effectively. Therefore, future researchers can take into account the various aspects that have been discussed by researchers in this study to develop the potential of existing small-scale entrepreneurs by including various other elements to their study.

\section{References}

Bailey. (2006). A Guide to Qualitative Field Research, 128-129.

Bandura, A. (1992). Social Cognitive Theory. In Vasta, R. (pnyt.). Six Theories of Child Development, 15-26. London; Jessica Kingley Publisher.

Dayang, H. T., (2011). Qualitative Data Analysis (2nd Edition). August Publication.

Plsek, P. E. (1996). Working paper: Models for the Creative Process. http://www.directedcrativity.com/pages/tools/preps.html (27 Jan)

Rosli, M. (2010). Pembiayaan Perniagaan. Di dalam Rosli, M., Azrain, N., Rosli, Mohamad, Y., Norria, Syahrina, A., K., Hoe, C. Y., Shamsul, H., Muhammad, S., Shiza, S., Lily, J.,Habshah. Prinsip-prinsip Keusahawanan (2nd Edition). Singapore: Cengage Learning Asia Pte Ltd.

Syahrina, A. (2010). Mengenali Ciri-ciri Usahawan. In Rosli, M., Azrain, N., Rosli, M. Y., Norria, Syahrina, Ahmad, K., Hoe, C. Y. Shamsul, H., Muhammad, S., Shiza, S., Lily, J., Habshah Prinsip-prinsip Keusahawanan (2nd Edition). Singapore: Cengage Learning Asia Pte Ltd, 229-250 